\title{
The Moral Significance of Abortion Inconsistency Arguments
}

\author{
William Simkulet ${ }^{1,2}$ D
}

Received: 13 July 2021 / Revised: 2 September 2021 / Accepted: 7 September 2021 /

Published online: 29 October 2021

(c) National University of Singapore and Springer Nature Singapore Pte Ltd. 2021

\begin{abstract}
Most opponents of abortion (OA) believe fetuses matter. Critics argue that OA act inconsistently with regards to fetal life, seeking to restrict access to induced abortion, but largely ignoring spontaneous abortion and the creation of surplus embryos by IVF. Nicholas Colgrove, Bruce Blackshaw, and Daniel Rodger call such arguments inconsistency arguments and contend they do not matter. They present three objections to these arguments - the other beliefs, other actions, and hypocrisy objection. Previously, I argued these objections fail and threaten to undermine ethical inquiry. Colgrove et al. have recently replied, but here, I argue their reply fails as well and raises a new criticism of the other actions' objection. This essay sets out to show, as well as any philosophical argument can, that inconsistency arguments are morally significant.
\end{abstract}

Keywords Abortion · Reproductive ethics · Spontaneous abortion · Frozen embryos $\cdot$ Restrictivism

\section{Introduction}

Nicholas Colgrove, Bruce Blackshaw, and Daniel Rodger (2020) set out to show that inconsistency arguments "do not matter"; by inconsistency argument, they mean to pick out a variety (Fleck 1979; Murphy 1985; Ord 2008; Lovering 2013, 2014, 2017 , 2020; Berg 2017; Simkulet 2016, 2017, 2019a, b, c, 2020; Bovens 2006; Schlumpf 2019) of disparate criticisms identifying apparent inconsistencies in how opponents of abortion (OA) treat fetuses. Unfortunately, this term is misleading, as practically all philosophical arguments involve identifying some form of inconsistency, confusion, or misunderstanding.

\section{William Simkulet}

Simkuletwm@yahoo.com

1 Park University, Parkville, MO, USA

2 Dodge City Community College, Dodge City, KS, USA 
Critics of the prolife anti-abortion position argue that OA hold inconsistent moral beliefs; they claim to believe that fetuses are persons from conception, but they neglect the welfare of fetuses who are spontaneously aborted by natural causes, and overlook the well-being of the surplus frozen human embryos created for IVF. Perhaps the strangest argument that Colgrove et al. (2020) label as an inconsistency argument comes from Sister Joan Chittister (Schlumpf 2019), who chastises those who call themselves "pro-life" for neglecting the welfare of born persons. Proponents of inconsistency arguments argue that OA hold inconsistent moral beliefs, arguing that upon revision, they will conclude that they either (i) need to do more, or (ii) need not oppose abortion.

Colgrove et al. (2020) contend that such arguments "do not matter." This paper interprets this as the claim that inconsistency arguments are morally irrelevant for any (widely held) OA view. This paper will show that such arguments are morally relevant to the most widely held OA position.

Another way to read Colgrove et al. is as claiming they "do not matter" because they cannot show that OA need to adopt (ii) over (i). They say, "Inconsistency arguments simply are not equipped to undermine OAs' views; at most, they reveal what OAs should do (or believe)." (Colgrove et al. 2020) This is uncharitable. First, while some inconsistency theorists (Ord 2008; Berg 2017) might believe that OA do not really believe fetuses are persons from conception, these arguments identify apparent inconsistency, but need not take a stance on how OA ought to resolve this inconsistency. Second, even if OA choose (i) and conclude they ought to do more to prevent spontaneous abortion (education, research, increased access to healthcare (Simkulet 2017, 2020), and perhaps a major shift in social priorities (Ord 2008; Berg 2017), and more for surplus IVF embryos (adoption, and gestation (Lovering 2020; Blackshaw and Colgrove 2020; Blackshaw 2021), this matters. Colgrove et al. jest that if OA embrace option (i) it would "make the world a (much) worse place (from the critic's perspective)"; but fail to note that it would make the world a much better place from the perspective of OA!

Complicating matters, there seems to be disagreement among Colgrove, Blackshaw, and Rodger regarding what opposition to abortion requires. Notably, Bruce Blackshaw $(2021,166)$ contends that Christians ought to act as neighbors, and offers a robust, clear account of what this requires:

Treating frozen embryos as neighbors requires securing them a life like ours through adoption and gestation, and as well as opposing abortion, Christians must work toward this goal for the vast numbers of frozen embryos that would otherwise be discarded.

Blackshaw and Rodger (2019) attempt to justify OA disinterest in spontaneous abortion, claiming that most cases of spontaneous abortion are not currently preventable; but Blackshaw (2021) notes that "if we regard all human life as equally valuable, we have at least some obligation toward helping reduce deaths from spontaneous abortion where possible". 
This paper argues that inconsistency arguments matter. It is divided into three main sections. The first draws a distinction between restrictivist and moralist views on abortion, arguing only restrictivist views are OA. The second sets out to defend my earlier criticism (Simkulet 2021) of the other beliefs, other actions, and hypocrisy objections from Blackshaw et al.'s (2021) recent response. The third offers a new argument against the other actions objection; I argue that if this objection were to succeed, it would undermine restrictivist opposition to abortion.

\section{Opposition to Abortion}

\section{On Miscarriage}

Before his collaboration (Colgrove et al. 2020) with Blackshaw and Rodger, Colgrove (2019) raised a different criticism of Berg's (2017) inconsistency argument. Berg argues that because miscarriage is so common, if we believe fetuses matter, we ought to devote more medical resources to protecting them. Colgrove replies that "miscarriage is not a cause of death," but rather "it is an outcome." Blackshaw et al. (2021) accuse me of the same error.

This is rather uncharitable, but it also misses two key points common in inconsistency arguments. First, if OA believe that fetuses matter, one would expect them to be concerned with both spontaneous and induced abortion, as both are tragic. Second, even if spontaneous abortion has many disparate causes, there may be a common solution. For example, Aspirin can treat a wide variety of conditions, from scraped knee to eye strain to migraine. Many proposals inconsistency theorists discuss (for example, education, gene therapy, and ectogenesis technology) would prevent spontaneous abortion by many different causes. In short, even if miscarriage is not a single cause of death, there is good reason to think a single solution might address many different cases, saving many fetal lives.

\section{On Opposition to Abortion}

To play on Colgrove, note that opposition to abortion is not a moral theory, it is an action or stance one can take toward abortion. There are many reasons why one might oppose abortion; one might merely find the word "abortion" to be distasteful, might oppose abortion on teleological grounds, argue that it is outside the scope of medicine, or that it violates the Hippocratic Oath.

However, most opposition to abortion rests on a single belief. Judith Jarvis Thomson (1972) says, "Most opposition to abortion relies on the premise that the fetus is a human being, a person, from the moment of conception." Don Marquis (1989) says "Many of the most insightful and careful writers on the ethics of abortion... believe that whether or not abortion is morally permissible stands or falls on whether or not a fetus is the sort of being whose life it is seriously wrong to end."

In short, most opposition to abortion turns on the belief that a fetus matters from conception (or soon afterwards (Marquis 2007, 2013); that the fetus is morally comparable to an adult human person. This view is usually abbreviated as the view that 
fetuses are persons, broadly construed to mean one of many disparate theories about moral status; that human fetuses are human organisms (Mulder 2013), rational substances (Lee and George 2005; Beckwith 2007; George and Tollefsen 2008; FribergFernros 2015), have a possible future it would be wrong to deprive them of Marquis 1989; Stone 1987), etc.

Colgrove et al. (2020) seek to show that inconsistency arguments are morally irrelevant for any (widely held) anti-abortion view, and there seems to be widespread consensus the most widely held anti-abortion view claims fetuses are persons, broadly construed, from conception (PAC). This paper defends the position that inconsistency arguments are morally relevant to the PAC view.

\section{Restrictivism and Moralism}

It will be practical to distinguish between two groups of anti-abortion positions -Restrictivism (Davis 1984; Carroll and Crutchfield Forthcoming), the view that we should adopt social policies that restrict a woman's access to induced abortion, and Moralism, the view that abortion is merely immoral, but that we do not need adopt Restrictivist social policies.

It is not hard to see why PAC theorists might embrace restrictivism. On this view, fetuses are comparable to adult human persons, and society has adopted policies aimed at protecting the rights of adult human persons, so it is prima facie plausible that we should adopt similar social policies regarding fetuses. However, Thomson (1972) demonstrates that it is not enough to show that fetuses merely have a right to life by way of the violinist case:

Violinist: The Society of Music Lovers kidnaps you and attaches your circulatory system to a famous, innocent, unconscious violinist suffering from a kidney ailment that will kill him unless he remains connected to your kidneys for nine months. (Adapted)

The violinist obviously has a right to life, but Thomson argues that the right to life does not give him the right to use your body; it is morally permissible for you to disconnect yourself from the violinist. Thomson says it would be a "great kindness" to stay attached to the violinist but that you do not have to accede to this.

Disconnecting the violinist from your body is comparable to disconnecting a patient from life support to let him die. Restrictivists might argue that induced abortion is not a matter of letting die; but of killing; but this will not do, as one can terminate a pregnancy without killing the fetus by severing the umbilical cord or removing the uterus, "merely" letting the fetus die. If this distinction mattered, restrictivists would not be anti-abortion, they would merely oppose how most abortions are currently performed.

Thomson shows it is not enough for restrictivists to believe fetuses are persons with a right to life, they must also believe something more, that (a) the fetus's right to life is a positive right to assistance, or (b) the gestational mother somehow comes to have a special obligation to provide assistance to the fetus. She argues that this special obligation cannot be explained by merely risking the chance of pregnancy, as this would imply any woman who leaves the house without a hysterectomy has 
consented to pregnancy, even by rape. Furthermore, David Boonin (2002) argues that even if one consents to provide aid, one can withdraw consent.

Bone Marrow: Your neighbor is diagnosed with a condition that will kill him unless he receives monthly bone marrow transplants over the course of nine months from a match. You are a match and you agree to donate. However, it soon becomes clear that these surgeries ask more than you are willing to give, and you refuse to go in for the second surgery. (Adapted)

These thought experiments demonstrate that restrictivists must do more than argue fetuses are persons, they must argue that the fetus has a positive right to assistance.

However, one can believe abortion is immoral without believing we ought to adopt restrictivist social policies. There are many prima facie immoral things that it would be inappropriate to restrict by law. For example, I think most of us would agree that it is prima facie immoral to waste scarce resources, but that individuals might have a right to do so in some cases. One might hold that it is wrong to waste food without holding that throwing away leftovers should be illegal. Similarly, one might hold that adultery outside of an open marriage is immoral, but that adopting social policies that restrict such behavior would be undesirable, in part, because they are difficult to enforce, and in part because it might incentivize other immoral behavior, such as murdering one's spouse to keep one's adultery secret.

Moralism is the view that abortion is often, all things considered, immoral, but does not require that we adopt social policies that restrict woman's access to abortion. There are many reasons why moralists might reject restrictivism independent of Thomson and Boonin-style concerns.

For example, restrictivist views have a hard time making exceptions for rape cases, despite the fact that many restrictivists believe such exceptions should be made. Rape victims are often reluctant to report rape and reluctant to take medical exams. Convictions in rape cases are difficult to obtain, especially within the short window in which inducing abortion would be medically preferable. As such, restrictivists face a dilemma - (a) if they require proof of rape, then few rape victims are allowed to abort; while (b) if they do not require proof of rape, they encourage women to merely say they were raped (whether true or not), failing to prevent most induced abortions and encouraging deception.

Restrictivists face a similar challenge with regards to self-defense, as all pregnancies are medically risky. The prospect of drawing a nonarbitrary line with regards to legally obligatory medical risk is dubious, but even if such a task could be achieved, those physicians sympathetic to abortion might overestimate risk and those opposing abortion might underestimate or ignore risk. Furthermore, medical risk of abortion increases with malnutrition and other medical emergencies, so those seeking abortion on medical grounds are incentivized to harm themselves to pass this threshold.

In light of these, and other, difficulties, many people who believe abortion are immoral reject restrictivism and adopt moralism. Notably, moralists need not hold that fetuses have a positive right to assistance, like restrictivists. I have contended (Simkulet 2021) that most OA believe fetuses have a positive right to assistance that most OA are restrictivists. Blackshaw et al. (2021) claim that I miss "the target," 
as one can be an OA without being committed to the belief that fetuses have a positive right to assistance.

Perhaps Colgrove et al. wish OA to pick out both restrictivist and moralist positions, but this will not do. Although moralists believe induced abortion is immoral, they are prochoice, while Colgrove et al. identify OA as prolife. Perhaps Colgrove et al. mean to say restrictivism does not require the belief that fetuses have a positive right to assistance, but this would merely introduce greater inconsistency regarding medical and legal ethics, as illustrated by Thomson (1972) and Boonin (2002).

\section{Do Inconsistency Arguments Matter?}

Colgrove et al. (2020) raise three objections to inconsistency arguments - the other beliefs, other actions, and hypocrisy objections. I contend (Simkulet 2021) these objections threaten to undermine moral analysis completely; opposing parties could always claim to have other beliefs, other actions, or interpret criticism as an ad hominem attack impinging their character.

This section is divided into four subsections. The first looks at two inconsistency arguments. The next three subsections briefly summarize Colgrove et al.'s objections, and my criticisms (Simkulet 2021) of these arguments.

\section{Inconsistency Arguments}

OA often point to high numbers of induced abortion as a call to action. Upwards of 60\% (Boklage 1990; Léridon 1977) of human pregnancies end in spontaneous abortion, prompting critics to ask why OA do not see spontaneous abortion as a call to action. Toby Ord (2008) compares spontaneous abortion to a scourge that kills over half of humanity. Berg (2017) compares it to Heart Disease, Cancer, and Stroke. Faced with these overwhelming numbers, inconsistency theorists conclude that if fetuses matter, then the problem of spontaneous abortion calls for a massive shift in our social and political priorities. I have noted (Simkulet 2021) that we recently underwent such a shift to address the COVID-19 pandemic.

Henrik Friberg-Fernros (2015, 2019, 2018) challenges this position, contending that while fetal death is always tragic, not all fetal deaths are equally tragic; that killing is worse than letting die, and even that fetal lives are worth less than adult human lives because they lack time relative interests (Friberg-Fernros 2019)! However, inconsistency arguments do not assume that all fetal deaths are equally tragic, merely that if fetuses matter, their deaths are tragic.

OA face a dilemma - either they (i) need to do more to prevent fetal death, or (ii) should withdraw opposition to induced abortion. Some proponents think OA should choose (ii) - that the argument demonstrates they do not really believe fetuses are persons. However, others propose a wide variety of methods by which OA might reasonably seek to confront the problem of fetal death, from increased education and better access to healthcare, to technologies like ectogenesis and gene therapy that those on both sides of the abortion debate could reasonably support (Simkulet 2020). 
While many inconsistency arguments focus on unaddressed fetal loss, Colgrove et al. (2020) also categorize Chittister's tweet (Schlumpf 2019) as an inconsistency argument. She asks whether it makes sense to call OA "pro-life" merely because they oppose abortion, noting all OA seem to be concerned with is ensuring the child is born, not fed, educated, or housed; asserting "That's not pro-life. That's pro-birth."

Colgrove et al. (2020) contend that Chittister is using the term "pro-birth" pejoratively, but this is rather uncharitable. The term "pro-life" carries with it a positive emotive context, and when OA present their view as "pro-life," they may mislead their audience about their position. In contrast, the term "pro-birth" seems to capture the one unifying feature of OA.

Even if Chittister is angry or disappointed that OA misrepresent their position, neglect their moral obligations, or the like... so what? That is how moral judgements work. If you think $\Phi$ ing is wrong, and you see someone $\Phi$ ing, it makes sense to be angry or disappointed. Colgrove et al. speak as though this, and accusations of pro-life hypocrisy are ad hominem attacks on OA; not so. An ad hominem fallacy occurs when one attacks person rather than their argument or view. Inconsistency arguments do not do this; they identify apparent inconsistency within the OA view, and call for change, as Chittister does when she concludes, "We need a much broader conversation on what the morality of pro-life is."

\section{Other Beliefs Objection and Response}

Colgrove et al. (2020) raise three objections to inconsistency arguments. In the first, they contend that inconsistency arguments do not matter because there is a diversity of beliefs among OA, suggesting that no one inconsistency argument undermine them all; "This diversity makes broad accusations of inconsistency problematic." Following this, one might argue that when an OA is confronted with apparent inconsistency within one view, they can jump ship to another OA view. But moral analysis is not a shell game. If inconsistency arguments identify a problem within even one OA position, they matter; and if they threaten the most widely held OA position, it seems they matter quite a bit.

Colgrove et al. (2020) suggest that OA may have other beliefs which explain away apparent inconsistency and justify their inaction with regards to spontaneous abortion; for example they ask us to consider someone who both opposes induced abortion and opposes universal healthcare; noting these beliefs would justify rejecting the conclusion that we should adopt universal health care to help address the problem of induced and spontaneous abortion (and suffering and death due to lack of medical care, more broadly). To this, I reply (Simkulet 2021):

It is not enough to show that some [OA] have some beliefs that are prima facie at odds with some [inconsistency theorist] proposals; they must show that the current level of apparent indifference that many [OA] show is justified by their other beliefs; and it is not clear what set of other beliefs would be both internally consistent and justify the conclusion that while persons [matter], this right requires very little in the way of sacrifice from anyone but gestational mothers. 
Blackshaw et al. (2021) contend that I argue "this [apparent] indifference must be justified by their other beliefs..." continuing "there is an obvious belief that justifies [OA]'s actions and priorities —... [OA] believe that induced abortion is a more important priority than these other issues." However, this misses the point. As we have seen above, inconsistency theorists do not claim that OA need to treat the problem of spontaneous abortion as equally important to the problem of induced abortion, but rather they must consistently recognize both are tragic.

Blackshaw et al. (2021) continue "induced abortion is the leading preventable cause of death of human beings, as spontaneous abortions are largely unpreventable." However, they seem to understand "preventable" in an opportunistically narrow way - as preventable with our current technology — to disregard the problem of spontaneous abortion. Amy Berg (2017) challenges this opportunistically narrow caveat:

But imagine throwing up our hands about a horrible disease... Imagine saying that we should let AIDS, or cancer, or heart disease take its course, rather than expending more effort researching how we might prevent that disease or treat people who contract it. That's not what we do.

Berg (2017) notes that just because spontaneous abortion is medically intractable now does not mean it will be in the future, comparing to the AIDs epidemic, "In just a couple of decades, AIDS went from a mysterious underground disease, to a devastating and fatal epidemic, to a relatively manageable chronic condition."

Perhaps more troublingly, Blackshaw et al. (2021) say, "If OAs sincerely believe these claims, then they are acting consistently with their beliefs, and the Other Beliefs Objection succeeds." Above I have argued that even if one sees one form of abortion as a greater priority than another, this does not justify apparent indifference OAs show with regards to spontaneous abortion.

The real challenge here is "sincerity," most people have inconsistent beliefs of one form or another and do not realize it; but it is possible that one can realize that they hold two sincere beliefs while also sincerely believing those beliefs to be inconsistent. Consider the problem of evil; one might sincerely believe that God exists, that evil exists, and that God would not allow evil to exist. This belief set is inconsistent, but does not necessarily yield conflicting implications for how we ought to live our lives.

But what if an OA sincerely believes the following?

(a) All human death is morally tragic.

(b) Not all human death is morally tragic.

(c) Propositions (a) and (b) are apparently a contradiction.

It is easy to imagine a Socratic dialogue in which Socrates helps an OA to express position (a) and proposition (b), prompting them to reconsider their position; what's less easy to imagine is what would happen if an OA freely admits proposition (c), but refuses to reconsider. Moral agency requires some degree of reason-responsiveness, 
and at least with regards to the topic at hand, it is not clear such an OA would be able to function as a moral agent without rejecting one of these three propositions.

Blackshaw et al. (2021) end their reply as follows "If critics of [OA] want to change the subject - to examining whether the things [OA] believe are true or false, rather than fixating on [OA's] alleged inconstancy — then [our] essay has succeeded." Here, they again miss the point of inconsistency arguments, as these arguments do set out to examine whether the things [OA] believe are true or false; if the principle of non-contradiction is true, and OA hold contradictory beliefs, then at least one of their beliefs are false!

Why do they miss this point? I cannot be sure, but at times Colgrove et al. (2020) and Blackshaw et al. (2021) talk as though inconsistency theorists are uniformly prochoice and hope to convince OA to abandon restrictivism; however, inconsistency arguments might just as easily lead one to believe they ought to do more to prevent spontaneous abortion, address surplus frozen human embryos, and the like. Some inconsistency theorists believe both would lead to less restrictivist opposition to abortion, but this is irrelevant.

What matters is that inconsistency arguments share the same form as the Socratic method, highlighting apparent inconsistency and prompting introspection. Perhaps Colgrove et al. (2020) would also conclude that the Socratic method does not matter, but I hope not.

\section{Other Actions Objection and Response}

Colgrove et al.'s second criticism of inconsistency arguments is that they are too specific with their recommendations, suggesting OA can address problems raised by these arguments with different actions than those proposed by inconsistency theorists. For example, rather than adopt and gestate frozen human Embryos, as Lovering (2020) (and Blackshaw 2021!) advocate, Colgrove et al. (2020) suggest OA might fight "to change public perception of the status of embryos," or lobby to change IVF laws.

There are three problems here. First, although inconsistency theorists propose a variety of recommendations, these recommendations are not meant to be exhaustive, but rather representative of the kinds of changes an OA would need to adopt to resolve their apparent inconsistency. Remember, inconsistency theorists argue that OA face a dilemma - either (i) do more, or (ii) abandon their opposition to abortion; to say that an OA can perform other actions to address the problem just is to embrace the first horn of the dilemma.

Second, I have pointed out (Simkulet 2021) that the other actions Colgrove et al. (2020) propose are not necessarily mutually exclusive; one might both lobby to change IVF laws and adopt and gestate frozen human embryos. The fact that one lobbies to change IVF laws may reduce the number of surplus embryos created and frozen in the future; but it fails to address the needs of currently existing frozen human embryos, highlighting a third problem, that many of Colgrove et al.'s "other actions" are simply not enough. I illustrate (Simkulet 2021) this with a case inspired by James Rachels (1979): 
Jack $_{2}$ finds himself in a room with a starving child, surplus sandwich in hand. He receives a call... The caller asks, "Will you donate your sandwich?" and he replies, "I'll do you one better; I'm going to fight to change the public perception of the status of such starving children and raise awareness!" He proceeds to tweet about the starving child, sets up a donation page to help spread awareness, and posts pictures and videos of the child's deteriorating state. $\mathrm{Jack}_{2}$, an expert in such things, narrates as the child slowly dies.

Jack $_{2}$ 's claim to act to raise awareness pokes fun at Colgrove et al.'s (2020) proposal to protect frozen embryos by fighting to change public perception. Despite his tweeting, it is clear Jack ${ }_{2}$ fails morally - he lets a child starve to death when he could have easily saved that child's life.

Blackshaw et al. (2021) argue that this case is disanalogous to OA (in)action, arguing that OA "live in a world where there are many important issues clamoring for their attention," and suggest the following case is more analogous:

Jack $_{100}$ finds himself in a room with 100 needy children and only enough resources to save 1 child, which he does.

There are three substantive problems with this response. First, the case of $\mathrm{Jack}_{2}$ is not meant to be analogous to OA inaction (despite poking fun at it); it is meant to demonstrate that merely having other actions is not sufficient to show that inconsistency arguments fail.

Second, the case of Jack ${ }_{100}$ begs the question by assuming Jack is saving as many people as possible. However, as Lovering (2020) and Blackshaw (2021) seem to show, this simply is not how OA act. Inconsistency theorists argue that OA neglect to address the problems of spontaneous abortion, surplus frozen embryos, and even starving born children. Rather than save all they can, inconsistency theorists contend that OA act like Jack ${ }_{2}$, they do something, but fail to do everything they can.

Third, inconsistency theorists contend that most OA legislation and philosophical literature neglect to discuss the problems of spontaneous abortion, surplus frozen embryos, or starving born children. As such, perhaps the following case would be more analogous:

Jack $_{300}$ finds himself in a room with 300 needy children, and he says, "I see 100 needy children, but woe is me I can only save 1," and so he saves 1 child.

It seems Jack ${ }_{300}$ is unreliable; he says he sees 100 needy children in the room, but there are 300 needy children in the room. If we cannot trust Jack $\mathrm{J}_{300}$ to get an accurate headcount, it seems unreasonable to take his word that he is doing all he can.

With the Jack ${ }_{100}$ case Blackshaw et al. (2021) seem to abandon the other actions objection, instead arguing that OA, like $\mathrm{Jack}_{100}$, do the "most good" they can. In short, Blackshaw et al. seem to treat the other actions' objection as a surrogate for an argument from effective altruism, the view that we should try to do the most good we can. Colgrove et al. (2020) claim that there are many different beliefs about what it means to do the "most good", and suggest that objectively measuring options might be difficult, as though to claim that it does not matter what other actions OA take as long as they are trying to do the "most good." 
But this will not do. Effective altruism asks us to use reason and empirical evidence to maximize the amount of good we do, and inconsistency arguments seem to show that OA fail to do just this. Like $\mathrm{Jack}_{2}$, OA seem to ignore the easily preventable deaths of some with an unearned confidence that their current course of action is sufficient. If OA strive for effective altruism, they should be at least open to the prospect of embracing the first horn of the inconsistency theorist's dilemma - that maybe should do more. Suppose Jill ${ }_{100}$ finds herself in the locked room with $\mathrm{Jack}_{100}$, and promises to show $\mathrm{Jack}_{100}$ how he can save 3 needy children, rather than just 1, with the resources at hand; if Jack $_{100}$ seeks to be an effective altruist, should he not at least listen, time permitting?

Effective altruism requires that we guide our choices by reason and evidence; it is not enough to have a sincere belief that one is doing all that one can, the evidence has to back this up. If inconsistency theorists can show that OA are not doing all they can, then they have been succeeding in showing that OA fall short of effective altruism.

Of course, this is exactly what proponents of inconsistency theorists purport to show. Take the aforementioned inconsistency theorist Lovering (2020) who, like OA restrictivist Blackshaw (2021), argues that OA should do more than merely fight to change public perception or lobby to change IVF laws, in many cases they ought to also adopt and gestate actually existing frozen human embryos. Of course, not every OA can gestate frozen human embryos — without effective ectogenesis technology and universal healthcare this burden seems to fall on wealthy, female OA alone. However, few OA argue that adopting and gestating these embryos are obligatory for those with the means to do so, and this omission at least appears to be inconsistent with their assertion that all fetuses matter from conception, let alone the position that $\mathrm{OA}$ are acting as effective altruists.

Furthermore, Blackshaw (2021) does not merely side with Lovering regarding OA's obligations regarding frozen human embryos; he says:

[I]f we regard all human life as equally valuable, we have at least some obligation toward helping reduce deaths from spontaneous abortion where possible. The parable of the Good Samaritan reinforces the notion that Christians do have some responsibility toward this neglected group of human beings, who are also our neighbors.

Here Blackshaw (2021) contends that these groups - frozen human embryos and those fetuses who die from spontaneous abortion - matter, and that at least some $\mathrm{OA}$ - those inconsistency arguments seek to criticize - neglect them. In short, Blackshaw's (2021) view seems at odd with the view he expresses in Colgrove et al. (2020) and Blackshaw et al. (2021). This is not meant as a criticism of Blackshaw; philosophers revise their views over time, articles are often published long after their initial submission, and many articles are written for blind review which could disincentivize the author from discussing their previous works.

Note, however, that Colgrove et al. (2020) and Blackshaw et al. (2021) set out to argue that inconsistency arguments do not matter for any OA view and in doing so they bite off far more than they can chew. It is easy to contend that all OA have other possible actions - contra Frankfurt (1969), many philosophers 
believe alternate possibilities are required for moral agency and responsibility; but it is quite a different matter to argue that all OA are acting as effective altruists, or even that all OA merely sincerely believe they are acting as effective altruists, especially when confronted with criticism from inconsistency theorists. Blackshaw (2021) contends inconsistency arguments demonstrate that some OA neglect this group, and this alone seems sufficient to show inconsistency arguments are morally significant.

\section{Hypocrisy Objection and Response}

In their third objection, Colgrove et al. (2020) contend that inconsistency arguments aim to show that OA are hypocrites, rather than demonstrate inconsistency. I note (Simkulet 2021) that Colgrove et al. equivocate between hypocrisy and inconsistency, and that they characterize hypocrisy as a moral failing. Colgrove et al. (2020) say:

[OA] are often described as 'inconsistent' (hypocrites) in terms of their beliefs, actions and/or priorities...These objections notwithstanding, perhaps some OAs do act in ways that can be shown to be inconsistent with their beliefs. If so, then they are hypocrites. Hypocrisy is a serious charge regarding the character of OAs, but it has nothing to say regarding the validity and consistency of their beliefs - and OAs' beliefs are surely what critics should primarily be targeting.

In short, it seems that Colgrove et al. mischaracterize inconsistency arguments as ad hominem fallacies; but as we have already seen there is a difference. Inconsistency arguments are simply not aimed at showing OA are hypocrites; only that they have inconsistent beliefs.

In their reply to my previous work (Simkulet 2021), Blackshaw et al. (2021) say something bizarre "Simkulet offers no empirical evidence regarding [OA's] supposed lack of interest in relevant issues." But inconsistency theorists do this; Lovering (2020) goes to great lengths to discuss OA who do go out of their way to address these concerns and provides evidence such altruism is rare. Still, it is difficult to take this call for empirical evidence seriously, as neither Colgrove et al. (2020) nor Blackshaw et al. (2021) provide such evidence on behalf of OA.

Blackshaw et al. (2021) also challenge my claim (Simkulet 2021) that legislation seeking to reduce the creation of surplus IVF embryos would be relatively easy to pass:

Not so. Italy, for example, passed a law in 2004 prohibiting the freezing of embryos, and requiring that all embryos be implanted. (Riezzo et al. 2016) The law was swiftly condemned, eventually overturned and, in one case, actions prescribed by the law were declared by the UN to have constituted a 'human rights violation.' (Scaffidi 2019) Thus, relevant laws would likely 
face international resistance. So, a central problem Simkulet puts forth as having an 'easy' solution does not.

There are two big problems here. First, I propose (Simkulet 2021) passing legislation to limit the creation of surplus embryos, not to force all created embryos to be implanted. The difference is obvious, my restrictivist proposal would limit the number of embryos created at a time, so it might take multiple tries before a successful embryo is created.

In contrast, the Italian law seems to place no limits on how many embryos can be created, rather it sets out to force women to undergo invasive, risky medical procedures. IVF has a relatively low chance of success; but imagine more attempts at fertilization succeed than expected; this law would compel physicians to perform, and women to undergo, dangerous medical procedures against their wills. This is hauntingly similar to forcing you to donate bone marrow even at the cost of your life in Boonin's (2002) bone marrow case. In short, the Italian law threatens to harm citizens and undermine professional ethics by requiring medically risky and unnecessary interventions without the patient's consent.

In contrast, my proposal (Simkulet 2021) would merely require physicians limit the number of embryos created at one time; not entirely dissimilar from legal limits on how many drugs a physician can prescribe within a period of time. Furthermore, I do not say such legislation would be easy, only "relatively easy" compared to restrictivist legislation - legislation that has far more in common with the Italian law than Blackshaw et al. (2021) acknowledge. Both restrictivist legislation and the Italian law seek to undermine women's rights to control their body and force them to risk their lives for the sake of others. Meanwhile limiting the number of embryos created does not limit one's reproductive freedom, nor compel them to take on additional medical risk.

Both OA restrictivist legislation and the Italian law seek to limit women's reproductive choices and force women to take on additional medical risk. Legislation of this kind faces strong opposition from those seeking to protect women's liberty and reproductive freedom. This kind of legislation also faces strong opposition from biomedical ethicists and medical professionals, as it threatens to violate patient autonomy and the Hippocratic Oath by forcing patient and physician to perform risky medical procedures to benefit a third party, not unlike forcing you to remain attached to the violinist in Thomson's infamous violinist case (Thomson 1972).

In contrast, it is not clear that my proposed legislation (Simkulet 2021) to limit the number of embryos that can be created at a single time, would face much opposition at all. Perhaps eugenicists would oppose such legislation for limiting a parent's right to choose the "best" fetus from the widest possible net, but this does not seem like a widely held position. Perhaps bioethicists and medical professionals would oppose such legislation believing it cumbersome and impractical, but this seems like a much weaker ground for opposition than the autonomy and professional ethics violations epitomized by OA restrictivist legislation and the Italian law. 


\section{The Prochoice Other Beliefs Objection}

I have argued (Simkulet 2021) that if the other beliefs, other actions, and hypocrisy objections are not successful in showing inconsistency arguments "do not matter," they threaten to undermine the discipline of ethics. No person has merely one moral belief, so if a diversity of beliefs invalidates moral analysis, ethics is impossible. In all cases in which a person acts morally responsibly (save maybe some interpretations of Frankfurt-style cases (Frankfurt 1969), agents have other possible actions, so if merely having other actions was sufficient to disregard moral analysis, ethics fails. Finally, if interpreting moral analysis as an ad hominem attack of hypocrisy was sufficient to rebuff criticism, one can shut down all moral debate merely by being thin-skinned. Here, I have argued that Blackshaw et al. (2021) fail to defend these objections, and fail to show that inconsistency arguments do not matter.

However, these are lofty claims about the discipline of ethics; let's consider something a bit more down to Earth. Consider the following case:

Jacqueline is surprised to find herself pregnant, calling into question her school's sexual education program. While discussing the matter with her physician, she learns that some people believe embryos are persons from conception! She finds this view intuitive and compelling, and outraged by her school's poor sexual education program, she endeavors to work tirelessly to change the public perception of the status of embryos.

Later, her physician expresses concern about her exertion, recommending that she puts her efforts to educate on hiatus during the pregnancy, fearing the worst. Jacqueline faces a choice - (i) continue with her pregnancy for the next 6 months, losing ground on her fight to change public perception of embryos or (ii) induce abortion (perhaps by hysterectomy) and continue the fight.

When speaking with her physician, Jacqueline quotes an influential piece of literature (Colgrove et al. 2020), "It may be unclear, however, which option is superior. Many considerations apply to each, and they may be highly individualistic." She continues "Objectively evaluating options to determine the most appropriate action for a particular belief held by a specific individual seems a very difficult task." Upon careful and thoughtful reflection, she chooses (ii), judging that it will do the most good. After all, her embryo is but one embryo and while it is tragic to disconnect it from her body and let it die, her tireless efforts might do more good overall.

If the other actions objection shields OA from inconstancy arguments, it seems that it equally shields Jaqueline from restrictivist $\mathrm{OA}$ arguments that seek to restrict her freedom. Therefore, it seems that Blackshaw et al. face a dilemma - (i) reject the position that merely having other actions, beliefs, etc. is sufficient to shield a position from criticism, or (ii) abandon their opposition to induced abortion. If (i), then inconsistency arguments matter. Then again, if (ii), then it seems as though no ethical arguments matter. 


\section{References}

Beckwith, Francis J. 2007. Defending life: A moral and legal case against abortion choice. New York, NY: Cambridge University Press.

Berg, Amy. 2017. Abortion and miscarriage. Philosophical Studies 174(5): 1217-1226. https://doi.org/ 10.1007/s11098-016-0750-z.

Blackshaw, Bruce Philip. 2021. Is pregnancy really a Good Samaritan act? Christian Bioethics 7(2): 158168. https://doi.org/10.1093/cb/cbab004.

Blackshaw, Bruce Philip, and Daniel Rodger. 2019. The problem of spontaneous abortion: is the prolife position morally monstrous? New Bioethics 25(2): 103-120. https://doi.org/10.1080/20502877. 2019.1602376.

Blackshaw, Bruce Philip, and Nicholas Colgrove. 2020. Frozen embryos and the obligation to adopt. Bioethics 34(8): 857-861. https://doi.org/10.1111/bioe.12733.

Blackshaw, Bruce Philip, Nicholas Colgrove, Daniel Rodger. 2021. Inconsistency arguments still do not matter. Journal of Medical Ethics. https://doi.org/10.1136/medethics-2021-107644.

Boklage, C.E. 1990. Survival probability of human conceptions from fertilization to term. International Journal of Fertility 35(2): 75-94.

Boonin, David. 2002. A defense of abortion. New York, NY: Cambridge University Press. https://doi.org/ 10.1017/CBO9780511610172.

Bovens, Luc. 2006. The rhythm method and embryonic death. Journal of Medical Ethics 32(6): 355-356. https://doi.org/10.1136/jme.2005.013920.

Carroll, Emily, and Parker Crutchfield. Forthcoming. The duty to protect, abortion, and organ donation. Cambridge Quarterly of Healthcare Ethics.

Colgrove, Nicholas. 2019. Miscarriage is not a cause of death: a response to Berg's "abortion and miscarriage". Journal of Medicine and Philosophy 46(4): 394-413. https://doi.org/10.1093/jmp/jhab010.

Colgrove, Nicholas, Bruce Philip Blackshaw, Daniel Rodger. 2020. Prolife hypocrisy: why inconsistency arguments do not matter. Journal of Medical Ethics. https://doi.org/10.1136/medet hics-2020-106633.

Davis, Nancy. 1984. Abortion and self-defense. Philosophy and Public Affairs 13(3): 175-207.

Fleck, Leonard M. 1979. Abortion, deformed fetuses, and the Omega pill. Philosophical Studies 36(3): 271-283. https://doi.org/10.1007/BF00372631.

Frankfurt, Harry G. 1969. Alternate possibilities and moral responsibility. Journal of Philosophy 66(23): 829-839. https://doi.org/10.2307/2023833.

Friberg-Fernros, Henrik. 2015. A critique of Rob Lovering's criticism of the substance view. Bioethics 29(3): 211-216. https://doi.org/10.1111/bioe.12080.

Friberg-Fernros, Henrik. 2018. Within the limits of the defensible: A response to Simkulet's argument against the pro-life view on the basis of spontaneous abortion. Journal of Medical Ethics 44(11): 743-745. https://doi.org/10.1136/medethics-2017-104688.

Friberg-Fernros, Henrik. 2019. Defending the two tragedies argument: A response to Simkulet. Journal of Medical Ethics 45(6): 417-418. https://doi.org/10.1136/medethics-2019-105489.

George, Robert P., and Christopher Tollefsen. 2008. Embryo: A defense of human life. New York, NY: Doubleday.

Lee, Patrick, and Robert P. George. 2005. The Wrong of Abortion. In Contemporary Debates in Applied Ethics, ed. Andrew I. Cohen, and Christopher Heath Wellman. Malden, MA: Wiley-Blackwell.

Léridon, Henri. 1977. Human fertility: The basic components. Translated by Judith F. Helzner. Chicago, Il: University of Chicago Press.

Lovering, Rob. 2013. The Substance View: A Critique. Bioethics 27(5): 263-270. https://doi.org/10. 1111/j.1467-8519.2011.01954.x.

Lovering, Rob. 2014. The Substance View: A Critique (Part 2). Bioethics 28(7): 378-386. https://doi.org/ 10.1111/j.1467-8519.2012.02006.x.

Lovering, Rob. 2017. The Substance View: A Critique (Part 3). Bioethics 31(4): 305-312. https://doi.org/ 10.1111/bioe. 12330 .

Lovering, Rob. 2020. A moral argument for frozen human embryo adoption. Bioethics 34(3): $242-251$. https://doi.org/10.1111/bioe.12671.

Marquis, Don. 1989. Why abortion is immoral. Journal of Philosophy 86(4): 183-202. https://doi.org/10. 2307/2026961. 
Marquis, Don. 2007. The moral-principle objection to human embryonic stem cell research. Metaphilosophy 38(2-3): 190-206. https://doi.org/10.1111/j.1467-9973.2007.00481.x.

Marquis, Don. 2013. An argument that abortion is wrong. In Ethical theory: an anthology, 2nd ed., ed. Russ Shafer-Landau, 400-409. Oxford: Blackwell.

Mulder, Jack. 2013. A short argument against abortion rights. Think 12(34): 57-68. https://doi.org/10. 1017/S1477175613000080.

Murphy, Timothy F. 1985. The moral significance of spontaneous abortion. Journal of Medical Ethics 11(2): 79-83. https://doi.org/10.1136/jme.11.2.79.

Ord, Toby. 2008. The scourge: Moral implications of natural embryo loss. American Journal of Bioethics 8(7): 12-19. https://doi.org/10.1080/15265160802248146.

Rachels, James. 1979. Killing and starving to death. Philosophy 54(208): 159-171. https://doi.org/10. 1017/S0031819100048415.

Riezzo, Irene, Margherita Neri, Stefania Bello, Cristoforo Pomara, and Emanuela Turillazzi. 2016. Italian law on medically assisted reproduction: Do women's autonomy and health matter? BMC Women's Health 16: 44. https://doi.org/10.1186/s12905-016-0324-4.

Scaffidi, Sarah. 2019. Forced pregnancy in Italy violated 'woman's human right to health', UN experts rule. UN News, 27 March 2019. https://news.un.org/en/story/2019/03/1035601. Accessed 11 July 2021.

Schlumpf, Heidi. 2019. Sr. Joan Chittister's 2004 quote on 'pro-life' versus 'pro-birth' goes viral. National Catholic Reporter, 23 May 2019. https://www.ncronline.org/news/politics/sr-joan-chitt isters-2004-quote-pro-life-versus-pro-birth-goes-viral. Accessed 11 July 2021.

Simkulet, William. 2016. A critique of Henrik Friberg-Fernros's defense of the substance view. Bioethics 30(9): 767-773. https://doi.org/10.1111/bioe.12289.

Simkulet, William. 2017. Cursed lamp: The problem of spontaneous abortion. Journal of Medical Ethics 43(11): 784-791. https://doi.org/10.1136/medethics-2016-104018.

Simkulet, William. 2019a. Substance, rights, value, and abortion. Bioethics 33(9): 1002-1011. https:// doi.org/10.1111/bioe.12616.

Simkulet, William. 2019b. The two tragedies argument. Journal of Medical Ethics 45(5): 304-308. https://doi.org/10.1136/medethics-2018-105145.

Simkulet, William. 2019c. Two tragedies argument: Two mistakes. Journal of Medical Ethics 45(8): 562-564. https://doi.org/10.1136/medethics-2019-105587.

Simkulet, William. 2020. Abortion and ectogenesis: Moral compromise. Journal of Medical Ethics 46(2): 93-98. https://doi.org/10.1136/medethics-2019-105676.

Simkulet, William. 2021. The inconsistency argument: why apparent pro-life inconsistency undermines opposition to induced abortion. Journal of Medical Ethics. https://doi.org/10.1136/medet hics-2020-107207.

Stone, Jim. 1987. Why potentiality matters. Canadian Journal of Philosophy 17(4): 815-830. https://doi. org/10.1080/00455091.1987.10715920.

Stone, Jim. 1994. Why potentiality still matters. Canadian Journal of Philosophy 24(2): 281-293. https:// doi.org/10.1080/00455091.1994.10717370.

Thomson, Judith Jarvis. 1972. A Defense of Abortion. Philosophy \& Public Affairs 1(1): 47-66.

Publisher's Note Springer Nature remains neutral with regard to jurisdictional claims in published maps and institutional affiliations. 